\title{
Some soil physical and chemical properties of natural stands and plantations at different ages of stone pine in Biga (Çanakkale-Turkey)
}

\author{
Hüseyin Barış Tecimen ${ }^{1 *}$, Orhan Sevgi ${ }^{1}$, Muhammet Akkaya ${ }^{2}$, Ece Sevgi ${ }^{3}$, Çağla Kızılarslan \\ Hançer $^{3}$ and Ernaz Altundağ Çakır ${ }^{4}$ \\ ${ }^{1}$ Soil Science and Ecology Dept., Faculty of Forestry, Istanbul University-Cerrahpaşa,34473 Bahcekoy, \\ Istanbul, Turkey \\ ${ }^{2}$ Forest and Water Ministry, Directorate of Afforestation, Çanakkale, Turkey \\ ${ }^{3}$ Department of Pharmaceutical Botany, Faculty of Pharmacy, Bezmialem Vakif University, Istanbul,Turkey \\ ${ }^{4}$ Department of Biology, Faculty of Arts and Sciences, Duzce University, Duzce, Turkey
}

Corresponding author: hbarist@gmail.com

\begin{abstract}
Soil physical and chemical properties were compared in stone pine (Pinus pinea L.) plantations vs neighboring natural sites. The pine plantations were selected at ages of 3, 10, 20 and 30 in Biga (Çanakkale-Western Turkey) to harvest adequate sampling plots and the natural sampling plots were settled to the vicinity of the plantation plots. The soils were investigated in terms of chemical such as $\mathrm{pH}$ and $\mathrm{EC}(\mu \mathrm{S} / \mathrm{cm})$ and physical such as soil volume weight, fine soil weight and skeleton weight $(\mathrm{g} / \mathrm{L})$ which were taken from $0-5$ and $5-15 \mathrm{~cm}$ depths from 9, 5, 8 and 8 sites (30 sites in total) for 3, 10, 20 and 30-year-old sampling plots. We assumed that, plantation causes decrease at $\mathrm{pH}, \mathrm{EC}$, soil volume weight, fine soil weight and increase at skeleton weight which would have occurred because of tillage and in contrast, the soils in natural sites, should have the opposite properties of plantation sites. The results revealed that; $\mathrm{pH}$ was lower in natural plots than plantation at 20-year-old sites (no significant difference in other plots), EC did not show any significant difference between natural and plantation sites. Soil volume weight was higher in plantation plots than natural lands at 10 and 20-year-old sites; fine soil weight was higher in natural land which is in concordance with our hypothesis; and skeleton weight of natural sites was one third of plantation sites. The results showed that; soil chemical and physical properties do not alter immediately after the plantation of a natural site but is an efficient factor on soil.
\end{abstract}

Keywords: Stone pine, soil chemical properties, soil physical properties, Biga.

\section{Introduction}

Pine plantations in Mediterranean regions have widely been applied for their socio-economical attribute and conversion of shrublands to latter successional stages. Pausas et al. (2004) discussed and evaluated the traditional pine plantations in terms of social demands and their adaptable features to Mediterranean specific ecosystem properties such as drought and fire sensitivity with conclusion of alternative tree + shrub species combinations. Studies by Öztürk (1995) and Öztürk et al. (2002, 2008, 2010 and 2011) revealed that, pine plantations have shown a seriously increase at plantation of semiarid Mediterranean regions. Semiarid areas of Turkey are subject to interest of land management authorities to be assessed as more profitable lands within providing a response to social demand and resistant ecosystems to soil 
loss with erosion, fire (fire resistant species) and drought (deep root developing species are chosen preferentially).

Maquis lands occupy the majority vegetation type of the Mediterranean ecosystems, and they are fire and drought adapted. Even though; conversion of natural shrublands or maquis lands to the plantations is a globally common application to optimize the benefits from a given site. The plantations are expected to extensive utilization of ecosystem resources such as water, nutrients and below and above ground spaces, but review on plantations' effects on semiarid areas do reveal generally negative effects; enhanced runoff and soil loss thus within nutrient and organic matter loss; improvement on soil properties are extremely limited and additionally fauna is also affected negatively from plantations (Maestre and Cortina 2004). In the study by Andrés and Ojeda (2002), the diversity of woody and soft stem bearing plants are significantly lower in pine plantations compared to adjacent Mediterranean heathlands, which cause to ecosystem susceptibility in terms of floral and faunal biodiversity.

Plantation is an alteration of current ecosystem thorough soil treatments and by introducing some new species. According to the study by Perez-Bejarano et al. (2010); the soil properties differed under contrasting forest and shrub species that of (Pinus halepensis Mill, Quercus coccifera L., Juniperus oxycedrus L. and Rosmarinus officinalis L.) significantly on advantageous of $P$. halepensis and $Q$. coccifera while, they manifest the promotional effect of semiarid conditions and shrub species. Southern Marmara region is characterized mainly semi-drought climate and drought-fire adapted vegetations with typical Mediterranean tree species Pinus brutia and shrubby oak species. The study site is dominated by Pinus brutia Ten., Arbutus andrachne L., Phillyrea latifolia L., Pistacia spp., Cistus spp. Main goal of the current study is to investigate the effects of different aged plantations on soil physical and chemical properties and to reveal practical results to enlighten the future studies.

\section{Material and Methods}

\section{Study site}

The study area is located at southern Marmara region in Biga province (Çanakkale-Turkey), lies thorough north to south. According to the long term meteorological observation results; annual average, minimum and maximum temperatures are 14.0; 5.6 (January) and $23.1^{\circ} \mathrm{C}$ (July); annual average minimum and maximum precipitation values are 666; 12 (July) and $113 \mathrm{~mm}$ (January) respectively (Anon. 2017). The soils are mainly weathered formations of Pliocene rocks and also the accumulated deposits of volcanic rocks originated from Pliocene age (Y1kılmaz et al., 2002; Akkaya, 2008). The dominating vegetation type in study area are Calabrian pine and accompanying Mediterranean shrub species in locations where primary vegetation type exist and damaged Calabrian pine forests are replaced with secondary shrubby maquislands with species of Arbutus andrachne L., Phillyrea latifolia L., Pistacia spp., Cistus spp., Laurus nobilis L., Paliurus spina-christi Mill., Rhus spp., Rhamnus spp., Quercuscoccifera L., Oleaeuropaea L., Tamarix spp., Quercus ithaburensis subsp. macrolepis (Kotschy) Hedge \&Yalt.) and Quercus cerris L. (Topçuoğlu, 1966).

\section{Soil samples}

The soil samples were collected from 4 different locations to obtain the gradual age pattern. The ages of the plantations are 3,10,20 and 30 and the natural lands are mainly covered with native multiannual shrub and annual herbal species (Table 1). The soil samples were collected along a transect from native to plantation lands per $10 \mathrm{~m}$ intervals; from $0-5$ and $5-15 \mathrm{~cm}$ depths with stainless steel cores to get intact samples. The samples were stored in polyethylene bags till conveyed to laboratory and then they are subjected to soil analyzes. Soils were ground and sieved following air dried and weighed before and after the skeleton has been removed. The bulk (volume) weight of the samples were detected prior to grounding the soils. $\mathrm{pH}$ and $\mathrm{EC}$ were measured in $\mathrm{pHmeter}$ and $\mathrm{EC}$ meter from 1:2.5 soil solution. 
Table 1. Distribution of number of sampling sites to age classes.

\begin{tabular}{ccccc}
\hline Age & Site names & $\begin{array}{c}\text { Number of } \\
\text { sampled plots }\end{array}$ & Natural land & $\begin{array}{c}\text { Plantation } \\
\text { land }\end{array}$ \\
\hline 3 & Pekmezli & 9 & 4 & 5 \\
10 & Kepekli & 5 & 3 & 2 \\
20 & Ortuluce & 8 & 3 & 5 \\
30 & Ilyasalan & 8 & 3 & 5 \\
\hline
\end{tabular}

\section{Statistics}

Data collected, classified and interpreted to detect the statistical relations in between the treatments. The soil analysis results were compared in terms of age, soil depth and natural vs plantation subplots by ANOVA in JMP 13v. The homogeneity of variances was tested, and the results were subjected to Tukey HSD at p 0.001 and 0.05 significance levels.

\section{Results}

\section{Chemical properties}

According to a comparison between the natural and plantation sampling plots, $\mathrm{pH}$ showed a significant difference for the plots at age of 20 where $\mathrm{pH}$ was slightly lower in natural lands than plantation plots $(\mathrm{p}<0.05)$ (Figure 1-I). At other aged plots, we did not find any significant difference when compared natural vs plantation. The comparisons made to see the differences according to age, the data for natural and plantation plots were pooled but the depths were investigated separately; the results showed that; the $\mathrm{pH}$ was significantly higher at 10 -year-old plots in $0-5 \mathrm{~cm}$ (p: 0.0007) and at 3-year-old plots at 515 ( $\mathrm{p}<0.0001)$ depth soils (Table 2).

Electrical conductivity did not show significant difference between natural and plantation sampling plots. The results obtained with natural + plantation pooled for depth series of samples showed that; the EC is decreasing with the age (highest at youngest plots and lowest at older plots) for both $0-5$ (p: 0.0194 ) and 5-15 cm (p: 0.0464) soils (Table 2).

Table 2. Comparison of soil physical and chemical characteristics of sampled plots (Volume weight, Fine soil weight and skeleton weights are as $\mathrm{kg} / \mathrm{L}$ ).

\begin{tabular}{|c|c|c|c|c|c|c|}
\hline Depth & Age & $\mathrm{pH}$ & EC & Vol W & Fine $\mathrm{S} \mathrm{W}$ & Skl W \\
\hline \multirow{4}{*}{$\begin{array}{l}\tilde{0} \\
i n \\
\text { o }\end{array}$} & 3 & $5,87 \mathrm{~b}$ & $107,6 \mathrm{a}$ & $1160,5 \mathrm{ab}$ & $1081,9 \mathrm{a}$ & $78,7 \mathrm{~b}$ \\
\hline & 10 & $6,69 \mathrm{a}$ & $101,5 \mathrm{ab}$ & $1143,6 \mathrm{ab}$ & $784,7 \mathrm{~b}$ & $358,9 a$ \\
\hline & 20 & $6,12 b$ & $97,0 \mathrm{ab}$ & $1334,6 a$ & $960,2 \mathrm{ab}$ & $374,4 \mathrm{a}$ \\
\hline & 30 & $5,83 \mathrm{~b}$ & $52,7 \mathrm{~b}$ & $1005,5 b$ & $891,4 \mathrm{ab}$ & $114,2 \mathrm{~b}$ \\
\hline \multirow{4}{*}{$\begin{array}{l}\text { है } \\
\frac{n}{1} \\
\text { n் }\end{array}$} & 3 & $6,9 b c$ & $85,5 \mathrm{a}$ & $1270,2 \mathrm{ab}$ & $1195,1 \mathrm{a}$ & $75,1 \mathrm{c}$ \\
\hline & 10 & $6,18 \mathrm{a}$ & $86,0 \mathrm{a}$ & $1364,2 \mathrm{ab}$ & $724,1 \mathrm{c}$ & $640,0 \mathrm{a}$ \\
\hline & 20 & $5,77 \mathrm{~b}$ & $81,2 \mathrm{a}$ & $1393,3 \mathrm{a}$ & $938,2 b c$ & $455,2 \mathrm{~b}$ \\
\hline & 30 & $5,41 \mathrm{c}$ & $53,5 \mathrm{a}$ & $1175,5 \mathrm{~b}$ & $1067,7 \mathrm{ab}$ & $107,9 \mathrm{c}$ \\
\hline
\end{tabular}

The letters connect each parameter per depth separately. The significances for 0-5 cm; $\mathrm{pH} \mathrm{0.0007;} \mathrm{EC} \mathrm{0.0194;}$ Vol W 0.0008; Fine S W 0.0132 and Skl W p <0.0001 and for 5-15 cm; pH p<0.0001; EC 0.0464; Vol W 0.0418 ; Fine S W 0.0012 and Skl W p $<0.0001$. 


\section{Physical properties}

Volume weight of soils showed a significant difference at 10 and 20 -year-old plots where the volume weight of the soils were lower in natural sample plots than plantation plots $(\mathrm{p}<0.05)$ (Figure 1-II). The natural + plantation plots pooled data results showed that, the volume weight is highest in 20 -year-old plots and lowest in 30-year-old plots in both $0-5 \mathrm{~cm}$ (p: 0.0008) and 5-15 cm (p: 0.0418) depth of soils (Table 2).

Fine soil weight showed a significant difference at 3-year-old sites with slightly higher weighing in natural lands $(1273 \mathrm{~g} / \mathrm{L})$ than plantation plots $(1038 \mathrm{~g} / \mathrm{L})$. In 10, 20 and 30-year-old sampling plots, we did not reach to any significant difference between natural and plantation plots. When the natural and plantation data pooled and the sites with different ages were compared between each other, the results showed that; the highest soil volume weight has been detected in 3-year-old sites and the lowest fine soil weight in 10-year-old sites in both 0-5 cm (p: 0.0132) and 5-15 cm (p: 0.0012) depth of soils (Table 2).

The skeleton weight in natural sites $(33 \mathrm{~g} / \mathrm{L})$ was more than one third of plantation sites $(107 \mathrm{~g} / \mathrm{L})$. When the natural and plantation data pooled and the sites with different ages were compared between each other, the results showed that the lowest skeleton weight was detected in 3-year-old sites and the highest skeleton weight in 10-year-old sites for both 0-5 cm (p: 0.0008) and 5-15 cm (p: 0.0418) depths respectively (Table 2).

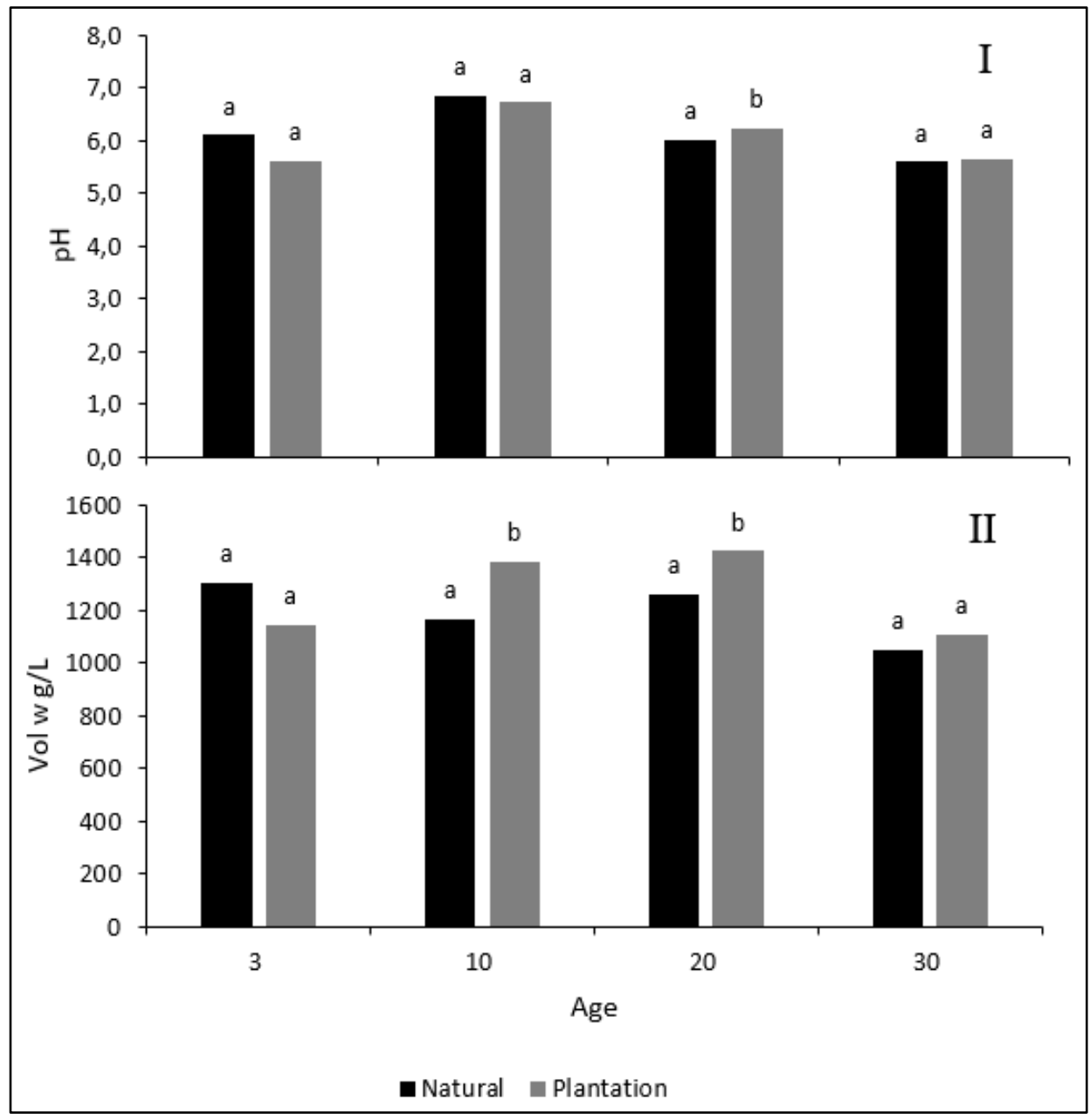

Figure 1. Comparison of $\mathrm{pH}$ and soil volume weight $(\mathrm{g} / \mathrm{L})$. 


\section{Discussion and Conclusion}

Plantation may differ soil $\mathrm{pH}$ depending on the plant species type and decomposition byproducts. The sites planted with stone pine are expected to decrease the $\mathrm{pH}$ by acidic humic substances. Indeed, in the study by Berthrong et al. (2009) stated that; afforestation of a nonforested land with pine trees or with other tree combinations deplete the soil cation saturation resulting in decrease in buffer capacity of soil and $\mathrm{pH}$. Over soil cation leaching because of tillage may cause to reduction in $\mathrm{pH}$. Plus, uptake of the cations by plants may cause to decreased $\mathrm{pH}$. In our study, the soil $\mathrm{pH}$ was lowest in 30 -year-old plantation sites while the differences between natural and plantation sites, $\mathrm{pH}$ was slightly but significantly lower in natural sites than plantation ( $\mathrm{pH} 6.12$ vs 6.18 at natural and plantation sites respectively). In the study by Tecimen et al. (2017), they detected particularly lower plant diversity in plantation sites. Despite the lower diversity, the species composition may have caused to decrease at soil $\mathrm{pH}$.

Site preparation prior to plantation supposed to be the most efficient factor on soil physical properties and subsequently in combination with soil tillage the plantation of the trees alters the soil chemical properties. According to the review study by Blanco-Canqui and Ruis (2018), no tilling is responsible to reduction of bulk density up to $13 \%$ at upper soil depths. In the study by $\mathrm{Su}$ and Zhao (2003) stated that; plantation with shrub species improved soil water holding capacity and decreased soil volume weight. Singh et al. (2001) found that; soil bulk density decreased along the age of the afforested landslide site from 1.74 to $1.15 \mathrm{~g} / \mathrm{L}$ at ages 1 to 58 respectively whereas mature forest has slightly lower soil bulk density. The results obtained from our study revealed that, the volume weight at natural lands vs plantation plots did not show any significant difference at immediate comparison (3-year-old plantation compared to natural sites). But at 10 and 20-year-old stands the volume weight values were higher at plantation sites than the naturally grown sites. When the natural and plantation data pooled the differences between sites in terms of age of trees showed that, volume weight was highest in 20 -year-old sites for both $0-5 \mathrm{~cm}$ and $5-15 \mathrm{~cm}$ depth of soil. The fine soil weight values were higher at 3-year-old natural sites compared to plantation sites and again the chrono-sequential comparisons revealed a higher fine soil weight at 3-year-old natural sites compared to others, when the natural and plantation data pooled. Studies on soil physical properties of plantations conclude that; the density (volume weight) of plantation sites are generally higher in initial years and progressively this value decreases to the density of natural field level. However, our results showed that, the highest volume weight among the sequential sites has been seen at 10 and 20-year-old stands.

We concluded that, stone pine plantation causes slight alteration at soil density and soil $\mathrm{pH}$ both of which are higher at plantation sites than the natural sites. Currently studied ecosystem possesses low soil cations and the tree species chosen for plantation are contented that may not exploit the soil cations and may particularly support the soil ecosystem with providing a shelter for floral and faunal diversity.

\section{Acknowledgement}

This work was supported by the Research Fund of The University of Istanbul under Project number 17298.

\section{References}

Akkaya, M. 2008: Effects of soil treatment techniques and planting spaces on forest soils in umbrella pine plantations (Pinus pinea L.) of Biga Regional Forestry Directorate. Ph.D. thesis, Forest Faculty, Istanbul University, Istanbul, Turkey. 
Anonymous. 2007: Turkish State Meteorology Service, IT Department (Devlet Meteoroloji İsleri Genel Müdürlüğ̈̈, Araştırma ve Bilgi Işslem Daire Başkanlı̆̆ı), Ankara.

Andrés, C., \& Ojeda, F. (2002). Effects of afforestation with pines on woody plant diversity of Mediterranean heathlands in southern Spain. Biodiversity \& Conservation, 11(9), 1511-1520.

Berthrong, S. T., Jobbágy, E. G., \& Jackson, R. B. (2009). A global meta-analysis of soil exchangeable cations, pH, carbon, and nitrogen with afforestation. Ecological Applications, 19(8), 2228-2241.

Blanco-Canqui, H., \& Ruis, S. J. (2018). No-tillage and soil physical environment. Geoderma, 326, 164-200.

Maestre, F. T., \& Cortina, J. (2004). Are Pinus halepensis plantations useful as a restoration tool in semiarid Mediterranean areas?. Forest Ecology and Management, 198(1-3), 303-317.

Ozturk, M., A. Celik, C. Yarci, A. Aksoy and E. Feoli. 2002. An overview of plant diversity, land use and degradation in the Mediterranean region of Turkey. Environ. Manag. \& Health., 13(5): 442-449.

Ozturk, M., I. Uysal, E. Karabacak and S. Celik. 2011. Plant species microendemism, rarity and conservation of pseudo-alpine zone of kazdagi (Mt. Ida) National Park in Turkey. Procedia-Social \& Behavioral Sciences, 19: 778-786.

Özturk, M., M. Gücel and Küçük, S. Sakçali. 2010. Forest diversity, climate change and forest fires in the mediterranean region of Turkey. J. Environ. Biol., 31: 1-9.

Ozturk, M., S. Gucel, S. Sakcali, C. Gork, C. Yarci and G. Gork. 2008. An overview of plant diversity and land degradation interactions in the eastern Mediterranean. In: Natural Environment \& Culture in the Mediterranean Region(pp. 215-239). Cambridge Scholars Publ., UK.

Ozturk, M.A. 1995. Recovery and Rehabilitation of Mediterranean Type Ecosystem: A Case Study from Turkish Maquis. In:Evaluating and Monitoring the Health of Large-Scale Ecosystems(pp. 319-331). Springer Berlin Heidelberg.

Pausas, J. G., Bladé, C., Valdecantos, A., Seva, J. P., Fuentes, D., Alloza, J. A., ... \& Vallejo, R. (2004). Pines and oaks in the restoration of Mediterranean landscapes of Spain: new perspectives for an old practice-a review. Plant ecology, 171(1-2), 209-220.

Pérez-Bejarano, A., Mataix-Solera, J., Zornoza, R., Guerrero, C., Arcenegui, V., Mataix-Beneyto, J., \& CanoAmat, S. (2010). Influence of plant species on physical, chemical and biological soil properties in a Mediterranean forest soil. European journal of forest research, 129(1), 15-24.

Singh, K. P., Mandal, T. N., \& Tripathi, S. K. (2001). Patterns of restoration of soil physciochemical properties and microbial biomass in different landslide sites in the sal forest ecosystem of Nepal Himalaya. Ecological Engineering, 17(4), 385-401.

Su, Y. Z., \& lin Zhao, H. (2003). Soil properties and plant species in an age sequence of Caragana microphylla plantations in the Horqin Sandy Land, north China. Ecological Engineering, 20(3), 223-235.

Tecimen, H. B., Sevgi, O., Akkaya, M., Sevgi, E., Hançer, Ç. K., \& Çakır, E. A. (2017). Comparison of species richness and diversity at natural stands and plantations of stone pine (Pinus pinea L.). Pak. J. Bot, 49(5), 17431748 .

Topçuoğlu, A. 1966. Utilization of Stone Pine Forests (Fıstıkçamı Ormanlarından Faydalanma)Tarım Bakanlığı, Orman Genel Müdürlüğü, Teknik Haberler Bülteni, Y1l:5 Sayı: 19. Ankara.

Yikilmaz, M. B., O. Aral and I. Özkar. 2002. A Pelagic Paleocene Stratification in Biga Peninsula (Biga Yarımadasında Pelajik Bir Paleosen İstifi). Mta Dergisi., 123-124: 21-26.

Zhang, K., Zheng, H., Chen, F. L., Ouyang, Z. Y., Wang, Y., Wu, Y. F., ... \& Xiang, X. W. (2015). Changes in soil quality after converting Pinus to Eucalyptus plantations in southern China. Solid Earth, 6(1), 115. 